\title{
Proposed Framework for Quality Assessment of E- government Portals in Saudi Arabia
}

\author{
Awatif Almurayziq \\ King AbdulAziz University \\ University of Hail \\ Saudi Arabia
}

\author{
Shaimaa Salama \\ King AbdulAziz University \\ Saudi Arabia \\ Faculty of Computers \& Al, Helwan University, \\ Egypt
}

\begin{abstract}
Governments in many countries are adopting information technology as a mean to deliver their services. Governments are encouraged to serve their citizens anytime and anywhere in an efficient way. Therefore, measuring the quality of these serving portals became a necessity. This study examines the quality of e-government portals in Saudi Arabia through introducing USR framework that contains three dimensions (usability, security and responsiveness), each dimention is associated with a set of sub dimensions. The framework is based on set of standards and theories for assessing the quality of e-government portals. In addition, the empirical data were gathered and collected by using self-administrated questionnaires distributed via social networking platforms to test the hypothesis indicated in the research and the data analysis was based on 3423 respondents in KSA. Using multivariate statistical techniques, the results indicated how each proposed dimention has effected e-government portals quality.
\end{abstract}

\section{Keywords}

E-government portals, On-line Service Quality, Measurement Model, Assessing quality, e-Services.

\section{INTRODUCTION}

E-Government is transferring the services of the government from its traditional form to an electronic-online form to improve the quality, efficiency and speed of the government services for the benefits. E-government has attracted the attention of politicians, scientists, and statesmen of the world in the recent years and have been extensively approached by governments in many countries. Many governments have devoted considerable efforts and resources, implement the online services. Responding to the increasing expectations of society, which now expects more than the basic services, a demand for advanced and electronic efficient services has been rising. The Kingdom of Saudi Arabia has witnessed a massive transformation in the span of a single generation. In 2005, the Ministry of Communications and Information Technology created the e-Government Program "Yesser" in coordination with the ministry of finance and Communications and Information Technology Commission (SAUDI, National e-Government Portal, 2017). Since then, the government has been upgrading to E-Systems. In this regard, there is a significant point to highlight, which is the concern of the quality of such systems that reflects their success or failure. Thus, more attention has been given to the measurement of e-government services in terms of quality. E-gcoverment services have influenced various stakeholders including policymakers, citizens, government employees, and information technology (IT) developers. This literature includes many models that were created to measure usability and effeciency of e-government services from various perspectives.Despite their objective to assist legislators and practitioners to measure the performance and improve the delivery of e-services, additional efforts need to be put to create a holistic model that could evaluate e-government services besides their communications with users[3]. In other words, the success of e-government services is amultifaceted concept, and its measurement must consider multidimensional factors [4]. The purpose of this study is to examine some of the emerging issues surrounding the egovernment portals quality in Saudi Arabia context. This study proposed a framework to measure the quality of egovernment portals in Saudi Arabia from a different perspective. The next section of this paper provides theoretical background and previous research related to measuring quality of e-government portals. Section three presents the proposed framework for assessing the quality of E-Government portals (USR) is presented. Subsequently, Section four addresses the research design and methodology. The fifth Section articulates data analysis and results. Finally, section six concludes the paper and discusses the future directions for this research the paper concludes with a discussion of research findings, recommendations for studies on e-government portals' and the future works are submitted.

\section{THEORETICAL BACKGROUND AND PREVIOUS RESEARCH}

This section will provide the readers a background of some terms and expressions that they need to be familiar with regarding the quality assessment of e-government portals. This section will emphasis the potential link between portal usability, security and responsiveness and e-government portals quality

\subsection{E-government Portals Quality:}

Quality of e-government portals:the term "quality" means characteristic, feature, trait. It refers to the sum of these characteristics against requirements. There is no single definition of quality. The reason is that quality has no clear defined specifications or baselines (Total quality management as a paradigm of business success, 2014).

E-Government service quality: There are two emerging terms: E-service quality and E-government service quality(Classification and synthesis of quality approaches in e-government services). E-service quality definitions are more e-business oriented and e-Government service quality is emphasizing e-government.E-service quality is defined by as "the extent to which a Website facilitates efficient and effective shopping, purchasing and delivery of products and services"(Technology readiness and e-service quality: insights for effective e-commerce, 2002).E-government service quality 
is defined as:"users' overall assessment of quality in the virtual context and serves as one of the key factors in determining success or failure of e-Government" (E-service quality model for Indian government portals: citizens' perspective, 2012).E-government service quality focuses on user interface of the web site (also portal) and on overall user satisfaction. E-government service quality definition can be combined with e-service quality definition as the extent to which government website facilitates efficient and effective delivery of public services. Website Usability: Drawing from the International Standards Organization's (ISO)(Quality management systems - Fundamentals and vocabulary - ISO $9000,2005)$ definition of usability, it has been defined as the extent to which a website can be used by citizens to achieve specified goals with effectiveness, efficiency, and satisfaction in a specified-government service context (adapted from[10]) .Moreover, defined web usability as a measure of the ease of accomplishing an intended tasks such as finding a given piece of information or buying a certain product (Web Usability. http://accessites.org/site/2007/07/web-usability, 2005).

Security, Security of a website means protection of information and systems against accidental or intentional disclosure to unauthorized access, or unauthorized modifications or destruction (Information Security: Design, Implementation, Measurement, and Compliance, 2007) . It refers to protection of the information architecture including network, hardware and software assets and the control of access to the information itself (E-government and Developing Countries: an Overview. International Review of Law Computers andTechnology, 2013).

Responsiveness This concept reflects the extent and the degree of which the e-government portal provides adequate assistance to users. It also specifies if there no delay is witnessed when responding back to citizens (as users). Any online user usually expects that the organization should effectively respond to his/her inquiries without any unneeded delay (Consumer perception of e-service quality: From Internet purchaser and non purchaser perspectives, 2002).

\subsection{Related Studies with Respect to E- government Portals Quality}

A wide stream of researches focused on the quality assessment of e-government portals based on several dimensions. [15] evaluated the usability of Saudi government websites using heuristic evaluation technique. The evaluation results identified many usability problems and highlighted areas for improvements. [16] proposed a scale that consisted of seven dimensions and 26 items for measuring the e-service quality in an e-government domain. The seven dimensions in this scale are: "Web site design, reliability, responsiveness, security/privacy, personalization, information and ease of use". The dimensions included SERVQUAL dimensions and two other dimensions, but they did not justify how these dimensions specifically apply to an e-government context. [17] proposed an e-government service quality model, eGovQual, where they indicate six constructs: ease of use, trust, functionality of the interaction environment, reliability, content and appearance of information, interactivity interaction[8]. [18] suggested a conceptual framework for assessing e-gov portals' success which integrates the updated Delone and McLean model, Technology Acceptance Model, self-efficacy theory and perceived risk. In this model 13 constructs are identified for assessing success of e-gov portals. The next model is guided by both TAM, D\&M model and the policies framed by the government of India. [19] assessed the quality of selected Polish e-government portals based on a proposed framework. They presented various definitions of quality and different theories/models for assessing the quality of e-government portals. Besides, they designed a framework for assessing the quality of e-gov portals is presented. The assessment of Polish e-government portals based on the proposed framework is shown. [20] suggested a framework with six usability characteristics that are necessary for evaluating e-Government systems. The framework usability characteristics represented as efficiency, security, accessibility, effectiveness, learn ability and usefulness. Reviews and interviews were used to collect data that analyzed using content analysis method. Two experienced experts validated the suggested framework. [21] evaluated the accessibility of the e-government services in Saudi Arabia through samples of 36 functional government websites in different governmental sectors. The results of the experiment showed an upgrading in the accessibility of Saudi government websites since 2010. [22] analyzed the influence of the quality services of the Ministry of Interior website in the United Arab Emirates. Many dimensions are analyzed such as website design, responsiveness, reliability, privacy, and information availability over the website. A questionnaire was used to collect data from the beneficiaries of the services that are available in the Ministry of Interior website. In addition, analyzing statistical methods were applied on the collected. [23] developed a theoretically derived framework for evaluating e-government. His study has expanded on previous works on e-government evaluation, value creation and effective use, which have been assessed via an SDL service ecosystem perspective.It is postulated that optimizing egovernment along these lines will drive effective use of egovernment and deliver sustainable public value.

This study proposes a new conceptual framework to measure the quality of e-government portals from different dimensions. The proposed framework is based on grounded theory of extensive review of related researches and international standards of e-government quality measurement models to identify the key performance indicators (KPIs) related to quality.

\section{THE PROPOSED FRAMEWORK FOR ASSESSING THE QUALITY OF E-GOVERNMENT PORTALS (USR)}

The proposed framework is based on extensive research on different theories and standards for e-government quality assessment. It contains three dimensions that are found the most common for Saudi culture based on previous researches and each dimension contains another sub-dimension to better examine the e-government quality. In the following sections, theories and standards for assessing usability, security and responsiveness will be discussed.

\subsection{Models for assessing e-government Portals' usability quality}

Because of the lack of fundamental theories of website usability, the previous studies had proposed different sets of website usability factors; using different terminology and scope. This elucidates the increasing numbers of publications in the literature have addressed the problem of how to measure software usability. Several different standards or models for quantifying and assessing usability have been proposed within the Human-Computer Interaction (HCI)field. Based on existing usability measurement standards or models, this study summarized that most researches overlapping various dimensions and sub-dimensions with different conceptions and descriptions. Moreover, most studies have 
handled usability as an important factor in assessing egovernment portals quality. Therefore, a research framework is drawn to clarify the linkage between usability and its associated components with quality of e-government portals, these sub-dimensions presented by Effectiveness, Efficiency, Accessibility, Navigation, Website content, Learnability, and Interface design. Sub-dimensions are selected that are identified are important to evaluate website usability focusing e-government portals quality, these sub dimensions have been applied in different countries but not well investigated in Saudi Arabia.

It should be noted that many studies have used Usability attributes that are mentioned in the current study with different definitions and functionalities. For instance, effectiveness has been used in various standards[20] ,[24], [25], [26],[27], [28], [29], [30] which as a metric is derived from measures of the quantity and quality of task output and measures whether users succeed in achieving their goals when working with a system (DRUM;[31] ).

Efficiency has been used in most standards and models as an attribute of system usability [28], [32], flexibility and efficiency of use[33], Efficiency of use [25], Performance Efficiency[20]. Significantly, it is noted that there is overlapping among usability attributes in concepts and functionality as efficiency is assumed to be related to navigation and Operability attributes. Navigation attribute is used in several standards in order to measure usability quality [28], [34], [35], [36] user control and freedom [33]Intuitive design [25], Operability[37], easy navigation [32]. Based on the current study framework, they have been defined as single attributes. Efficiency is defined as the capability of the software product to enable users to expend appropriate amounts of resources in relation to the effectiveness achieved in a specified context of use. Whereas, navigation ability is known as whether the user can move around in the application (system) in an efficient way.

Accessibility is very important factor of usability quality measurement that is used in many standards and models such as [28], [35], [36], [37], [20], [32]. Accessibility is recognized as the capability of a software product to be used by persons with some type of disability (e.g., visual, hearing, psychomotor). TheWorldWideWeb Consortium [38] suggested various design guidelines for making Web sites more accessible to persons with disabilities. Hence, accessibility differs to other attributes that is used to measure whether the system has applications that are oriented to serve people with disabilities. There are some issues that consider in accessibility such as cultural issues including language, color and symbols, social issues involving matters such as disability, gender and age, skills, economic factors and legal matters and technological issues that relate to computer, internet connections, telecommunications network and infrastructure [39]. [40] mentioned that Accessibility on Multiple Channels of government services through multiple channels enables wider reach and increased take-up of an egovernment portal [41]. Lately, other devices such as digital TVs, personal digital assistants (PDAs), and mobile phones are also being used to access Internet.

In addition, foreign language features on the portal allows access to non-native language speaking individuals. Foreign language access could be generally enabled through accessibility features such as text translation of the information into a language of choice [42].

Learnability means how easily the software tool is easy to learn for the users.Usability is closely related to ease of learning or learnability without necessarily implying a high performance in task execution. For instance, experienced users may be interested mainly in completing a wider range and number of tasks with minimal obstruction than with quickly completing a smaller range of tasks. This clarifies how a user can learn to operate, prepare inputs for, and interpret outputs of a system or component (IEEE Std.610.121990).

Website content should not be too crowded, because extraneous information on a webpage is a distraction and a slow-down. Website content attribute is used in many standards for instance Aesthetics and minimalist design [33], Content [34], website content [28], information delivery[35], Content organization [36], and Content usefulness [32]. Website content will be measured in the current study through the sufficiency of information provided on the website, meets user needed information, and whether the information provided on the site well organized. Interface design fundamentally focus on home page design facets, which have been the core of several standards and models[29], Consistency and standards [33], interface cohesion[34], User interface aesthetics[37], Home page[36], Screen Design [32]. The interface should ensure the consistency among the elements. For example, the design elements (font family, font size, font color, alignment) should be consistent and the operations for the same object should be consistent. Interface design used in the current study's framework will be measured via various tools such as website repeats the same structure, components and overall look across pages, whether Web pages in the website are consistently designed, and web site is presented in an attractive way, whether the interface of this web site is pleasant.Table: 1 demonstrate usability attributes of various standards and models. While table:2 explain website usability criteria matrix for the current study's framework and sources.

Accordingly, the following hypotheses, utterly formulated in the setting of Saudi Arabia, are predicted to be true. Hence, the first hypothesis is provided:

\section{H1: There will be a positive relationship between usability} and e-government portals quality.

\subsection{Security}

Security has been defined as the protection against threats such as a situation, condition, or incident with the potential to cause economic hardship to data or network resources in the form of destruction, nonprotection, modification, denial of services, fraud, mismanagement and abuse[48]. Several studies have found that security is a potential indicator for consumers to take online purchasing decisions[49]. With regards to e-government portals security can be conceived as transactional security, authentication, and protection against functional risks. Security builds trust between users and e government in specific or web sites in general. In the proposed framework, the security dimension is divided into two sub dimensions: Confidentiality and Identity authentication.

Confidentiality means the information is classified and cannot be published. In E-government system, important information should be encrypted to prevent unauthorized users from using the original data[50].

Identity authentication points that the users are verifying their identity to $\log$ in and use the system [51].

This process is called "Entity Authentication". This can be 
done with one of three kinds of witnesses: something known,

something possessed, or something inherent. Password, challenge-response, zero-knowledge, and biometrics are the most common authentication methods [51].

Table 1: Usability attributes of various standards and models.

\begin{tabular}{|c|c|c|c|c|c|c|c|c|}
\hline $\begin{array}{c}\text { Aziz and } \\
\text { Kamaludin(2015) }\end{array}$ & $\begin{array}{l}\text { Nielsen } \\
(1994)\end{array}$ & $\begin{array}{c}\text { Usability. } \\
\text { Gov } \\
(2018)\end{array}$ & $\begin{array}{c}\text { Project } \\
\text { Centre in } \\
\text { Poland } \\
(2013)\end{array}$ & $\begin{array}{c}\text { Stowers } \\
(2002)\end{array}$ & $\begin{array}{c}\text { ISO/IEC } \\
25010\end{array}$ & $\begin{array}{c}\text { Yahya } \\
\text { \&Razali } \\
(2015)\end{array}$ & $\begin{array}{c}\text { Venkatesh } \\
\text { \&Aljafari(2014) }\end{array}$ & $\begin{array}{l}\text { Anjoga et al } \\
\text { (2017) }\end{array}$ \\
\hline Efficiency & $\begin{array}{l}\text { Flexibility } \\
\text { \&and } \\
\text { efficiency } \\
\text { of use }\end{array}$ & $\begin{array}{l}\text { Efficiency } \\
\text { of use }\end{array}$ & & & $\begin{array}{l}\text { Performance } \\
\text { Efficiency }\end{array}$ & Efficiency & & \\
\hline Accessibility & & & & Accessibility & Accessibility & Accessibility & Access & Accessibility \\
\hline Navigation & $\begin{array}{l}\text { user control } \\
\text { and } \\
\text { freedom }\end{array}$ & $\begin{array}{l}\text { Intuitive } \\
\text { design }\end{array}$ & Navigation & Navigation & Operability & & Navigation & $\begin{array}{c}\text { Easy } \\
\text { Navigation }\end{array}$ \\
\hline Learnability & & $\begin{array}{c}\text { Ease of } \\
\text { Learning }\end{array}$ & & & Learnability & learn ability & & \\
\hline Interface design & $\begin{array}{l}\text { Consistency } \\
\text { and } \\
\text { standards }\end{array}$ & & $\begin{array}{l}\text { interface } \\
\text { cohesion }\end{array}$ & & $\begin{array}{c}\text { User } \\
\text { interface } \\
\text { aesthetics }\end{array}$ & & Home page & $\begin{array}{l}\text { Screen } \\
\text { Design }\end{array}$ \\
\hline
\end{tabular}

Table 2: Illustrates Website Usability criteria matrix for the current study's framework and sources.

\begin{tabular}{|c|c|c|}
\hline Sub dimensions & Description & Source \\
\hline Effectiveness & $\begin{array}{l}\text { The ability of software to enable user to achieve certain tasks in } \\
\text { a precise way. }\end{array}$ & $\begin{array}{c}{[20],[24],[25],[26] ;[27],[28],[29],} \\
{[30] .}\end{array}$ \\
\hline Efficiency & How fast an experienced user can accomplish tasks smoothly & $\begin{array}{c}{[33],[20],[24],[25],[26],[27],[28],} \\
{[43] .}\end{array}$ \\
\hline Accessibility & $\begin{array}{l}\text { Facilitates disability access features offered through an e- } \\
\text { government portal that ensures increased take-up of the portal }\end{array}$ & $\begin{array}{c}{[44],[35],[34],[33],[37],[20]} \\
{[36],[28],[45] .}\end{array}$ \\
\hline Navigation & $\begin{array}{l}\text { The system should be simple and convenient to use and provide } \\
\text { different entry points for different user groups. }\end{array}$ & $\begin{array}{c}{[44],[35],[34],[37],[36],[25],[28],} \\
{[46] .}\end{array}$ \\
\hline Website content & $\begin{array}{c}\text { The system should provide needed information and presents } \\
\text { information that is clearly organized. }\end{array}$ & [47], [34], [33], [36], [28], [46]. \\
\hline Learnability & $\begin{array}{l}\text { The ability of a system to enable user to feel that he/she is } \\
\text { effective and learns new functions fast. }\end{array}$ & $\begin{array}{c}{[35],[33],[37],[20],[25],[28],[29],} \\
{[45] .}\end{array}$ \\
\hline Interface design & $\begin{array}{c}\text { The looking of portal by users; portal pages are divided into } \\
\text { clear sections, consistent layout. }\end{array}$ & $\begin{array}{c}{[44],[34],[33],[37],[36],[25],[28],} \\
{[46] .}\end{array}$ \\
\hline
\end{tabular}

E-government website, integrated with many online transaction services, need users to provide personal information, therefore, it demands higher security or otherwise, it may lead to personal information disclosure or even worse to damage their benefits. Table 3 clarifies e- government portals security attributes as quality measurement. This leads to the second hypothesis:

H2 There will be a positive relationship between security and e-government portals quality. 
Table 3: E-government portals security attributes as quality measurement for the current study's framework and sources.

\begin{tabular}{|c|c|c|}
\hline Sub dimensions & Description & Source \\
\hline Confidentiality & $\begin{array}{l}\text { information is subjected to attack of sniffer or amend in the process of } \\
\text { transmission or storage }\end{array}$ & {$[50],[37],[52]$.} \\
\hline Identity authentication & $\begin{array}{l}\text { prevent illegal intervention, system should verify the legitimacy of the } \\
\text { user's identity }\end{array}$ & [51], [37]. \\
\hline
\end{tabular}

\subsection{Responsiveness:}

Responsiveness means that e-government communicates with citizens and respond to their suggestions and enquires [53]. When people deal with systems, they need a way to communicate their questions and enquires and expect a reply. However, some e-governments don't reply to citizen enquiries or even put invalid mail. This would have negative effect on the relationship between citizens and government[53]. Significantly, responsiveness is a crucial component that determines the service quality, which is provided by egovernment portals. Based on that, it is used in this study as a measurement for e-government service quality. The discussion leads to propose the final hypothesis as:

H3: There will be a positive relationship between responsiveness and e-government portals quality.

The dimensions need to be sought deeply to determine more detailed understanding of the dimensions themselves and their links with citizens' perceptions of e-government portals quality. Figure 1 demonstrates the USR framework and its involved dimensions.

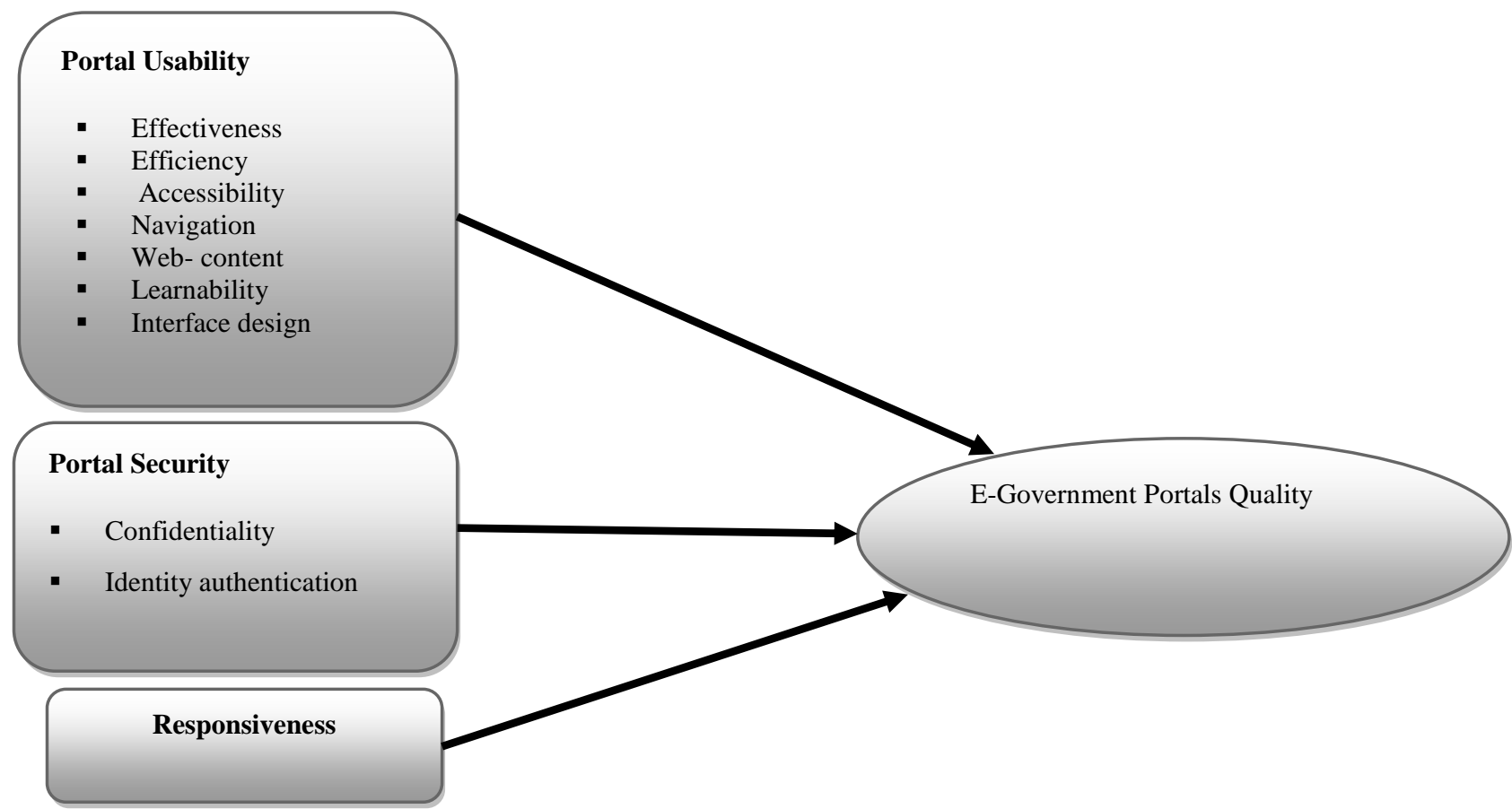

Figure 1: Conceptual Framework for E-Government portals Quality Assessment (USR)

\section{RESEARCH DESIGN AND METHODOLOGY}

This section articulates the research design and methodology applied in this study. A quantitative method is used employing self-administrated questionnaire. The self-administrated questionnaire was developed for data collection in three steps. First, several questions were developed based on prior similar studies and relevant literature in accordance with the hypotheses proposed. Second, a questionnaire pre-test was conducted to determine the accuracy and consistency of the responses. This comprised personally distributed and collected questionnaires. Last, the reliability and validity of the questions were tested. Revision was based on feedback from participants and statistical analysis. The questions were developed based on the comprehensive framework by using three main dimensions of e-government portals quality: usability, security, and responsiveness. All constructs were measured by using 5-points Likert type interval scales with 34 items. Each question is representing a component of the research model also questions relating to demographic and basic information of the respondents are also included. The questions included gender, age, education level, frequency of using government websites, and most used governmental website. The researcher has selected the websites in this study as they considered as the most used websites by the Saudi People according to [54] websites' classification. The highest proportion of government websites usage is given to the Ministry of Interior, Ministry of Education website and Ministry of Labor and Social Development this reflects that there is a high government websites usage in KSA. In addition, the questionnaire was transformed into electronic version, then distributed and collected through social media platforms such as Twitter and what's up. The final revised format of questionnaire was sent out to a large sample of 3423 respondents. 


\subsection{The Analysis Approach:}

The analysis process for the embarked study's framework is conducted within two stages: first, using multiple linear regressions for variables such as usability (Effectiveness, Efficiency, Accessibility, Navigation, Website Content, Learnability, and Interface Design) and security (Confidentiality and Identity authentication) with egovernment portals quality. While a simple linear regression used to explain the relationship between responsiveness and egovernment portals quality. Finally, in the last stage, one-way ANOVA is used as e-government portals quality perception was a category variable with two items. The general form of the multiple regressions equation for the variables included in this study is as follows:

\section{$Y=\beta 1+\beta 2 X 1+\beta 2 X 2+\ldots .+\beta n X n+\epsilon$,}

Where $\mathrm{y}$ is the response variable; $\mathrm{X} 1, \mathrm{X} 2 \ldots \mathrm{Xn}$ are the predictors variables; $\beta 1, \beta 2, \beta 3 \ldots . \beta \mathrm{n}$ are the partial regression coefficients, net regression coefficients or just regression coefficients, also $€$ is the error, or residual assumed to be random and normally distributed with equal variance at every $\mathrm{X}$ point [55]. According to the current study, Y represents e- government portals quality. Furthermore, X1, X2 .. Xn are the predictors.

\section{DATA ANALYSIS AND RESULTS}

Research results from quantitative analysis are based on a number of statistical techniques such as descriptive statistics, multiple linear regression, simple linear regression, and oneway ANOVA.

\subsection{Cronbach Alpha Test:}

Cronbach Alpha was used to measure internal consistency for stat survey and research variables, based on the sample estimation. In spite of the fact that researchers suggest 0.7 as the accepted cut-off [56] a value more than 0.6 is considered as a satisfactory level ([57]; [58]; [59]).These results were expected, as all the constructs and variables used in the study were based on well-established instruments with high reliability scores from previous studies. Table 4 illustrates that the results of the Cronbach Alpha test where for the main study survey and all research variables was greater than $60 \%$; this is acceptable in the social science research.

Table 4: Alpha Cronbach Test Results of Results of Main Study

\begin{tabular}{|c|c|c|c|}
\hline Variable & No. of Items & No. Of Cases & Alpha \\
\hline Usability & 22 & 3423 & $75 \%$ \\
\hline Security & 6 & 3423 & $83 \%$ \\
\hline Responsiveness & 4 & 3423 & $78 \%$ \\
\hline Perception of E-Government Portals Quality & 2 & 3423 & $70 \%$ \\
\hline
\end{tabular}

\subsection{Descriptive Statistics:}

\subsubsection{Demographic Information:}

This part presents descriptive statistics consisting of demographic information of the respondents and proportion of government websites usage. The frequency and percentage for each variable is listed as per the survey categories. The following table explains these results.

Table 5: Demographic Information

\begin{tabular}{|c|c|c|}
\hline Demographics & Number of respondents $=3423$ & $\%$ \\
\hline Gender: & 2109 & 61.6 \\
\hline Male & 1314 & 38.4 \\
\hline Female & & 56.4 \\
\hline Age: & 1930 & 30.1 \\
\hline $18-27$ & 1030 & 11.0 \\
\hline $28-37$ & 360 & 2.0 \\
\hline $38-47$ & 68 & 0.5 \\
\hline $48-57$ & 35 & 21.4 \\
\hline$>57$ & 281 & 8.2 \\
\hline Education: & 2150 & 62.8 \\
\hline High school & 205 & 6.0 \\
\hline Vocational/Diploma & 17 & 0.5 \\
\hline Bachelor & 38 & 1.1 \\
\hline Master & & \\
\hline Doctorate & & \\
\hline Other & & \\
\hline
\end{tabular}




\subsubsection{Government Websites Usage:}

Government websites using frequency: The majority indicated that they used the government websites less than once a month (37.7\%), 32.8\% have used government websites once permonth, $21.3 \%$ respondents have used government websites once per week, and $8.2 \%$ of respondents have used the government websites every day. As a result, the government websites have a high proportion of usage via the monthly use by the examined participants.

Most used governmental website: the researcher has selected the websites (table 6) in this research as they considered as the most used websites by the Saudi People according to Alexa (2019) websites' classification. The highest proportion of government websites usage given to

Table 6: Use of Government Websites

\begin{tabular}{|c|c|c|}
\hline Use of Government Websites & Number of respondents $=3423$ & $\%$ \\
\hline Using Frequency: & & 37.7 \\
\hline Less than once a month & 1290 & 32.8 \\
\hline Once per month & 729 & 21.3 \\
\hline Once per week & 281 & 8.2 \\
\hline Every day & & 53.5 \\
\hline most used governmental website: & 1831 & 32.6 \\
\hline Ministry of Interior & 4716 & 13.9 \\
\hline Ministry of Education & 476 & \\
\hline Ministry of Labor and Social Development & & \\
\hline
\end{tabular}

\subsubsection{Classification of Dimensions as an}

Applicable within Saudi Arabia context

Based on A survey of Saudi individuals; certain relationship exist between the components via the framework dimensions and their sub-dimensions with e-government portals quality. This confirmation of the relationships appeared between usability and its associated sub-dimensions (Effectiveness, Efficiency, Accessibility, Navigation, Website Content,
Ministry of Interior (53.5\%); followed by Ministry of Education website (32.6\%), Afterwards, Ministry of Labor and Social Development(13.9\%). Therefore; this reflects that there is a high government websites usage in KSA.These characteristics of individuals indicate that they have a reasonable understanding and a capability of dealing with information technology such as e-government portals. Additionally, the high proportion of male participating indicates that more acceptance of the survey from males than females, also in this society younger people using egovernment portals. This information is beneficial for policymaker in government agencies when launching technology projects dealing citizens. Therefore, thisreflects that there is a high government websites usage in KSA.

\section{Table7: Upshots of the Respondents' Classification of the Sub dimensions - High or Low}

\begin{tabular}{|c|c|c|c|}
\hline Dimensions & Mean & Proportion & The Results \\
\hline \multicolumn{4}{|c|}{ Usability: } \\
\hline Effectiveness of e-g portals & 3.79 & 75.8 & High \\
\hline Efficiency of e-g portals & 3.31 & 66.2 & High \\
\hline Accessibility of e-g portals & 3.33 & 66.6 & High \\
\hline Navigation of e-g portals & 3.64 & 72.8 & High \\
\hline Website Content of e-g portals & 3.55 & 71.0 & High \\
\hline Learnability of e-g portals & 3.75 & 75.0 & High \\
\hline Interface design of e-g portals & 3.55 & 71.0 & High \\
\hline \multicolumn{4}{|c|}{ Security: } \\
\hline
\end{tabular}




\begin{tabular}{|c|c|c|c|}
\hline Confidentiality of e-g portals & 3.53 & 70.6 & High \\
\hline Identity authentication & 4.00 & 80.0 & High \\
\hline Responsiveness & 3.66 & 73.3 & High \\
\hline E-Government portals Quality & 3.57 & 71.4 & High \\
\hline
\end{tabular}

Table 7 shows a high level of Effectiveness of e-government portals with $75.8 \%$, a high level of Efficiency of egovernment portals $(66.2 \%)$.Moreover, illustrates a high level of Accessibility of e-government portals with $66.6 \%$, a high level of navigation of e-government portals $(72.8 \%)$, a high level of website content of e-government portals (71.0\%), a high level learnability of e-government portals $(75.0 \%)$, a high level of interface design of e-government portals $(71.0 \%)$.

As per table 7 a high level of Confidentiality of e-government portals (70.6\%), also a high level of Identity authentication of e-government portals $(80.0 \%)$, and a high level of Responsiveness of e-government portals (73.3\%). Finally, a high level of E-Government portals Quality presented via (71.4\%).

\subsection{Testing the Hypotheses:}

The analysis process for the embarked study's framework is conducted within two stages: first, using multiple linear regressions for variables such as usability(Effectiveness,
Efficiency, Accessibility, Navigation, Website Content, Learnability, and Interface Design) and security (Confidentiality and Identity authentication) with egovernment portals quality. While a simple linear regression used to explain the relationship between responsiveness and egovernment portals quality. Finally, in the last stage, one-way ANOVA is used because e-government portals quality perception was a category variable with two items.

Hypothesis 1: Portal Usability vs. E-Government Portals Quality

To test this hypothesis, Multiple Regression Analysis (coefficient beta) was used between e-government portals Quality as dependent variable, and portal usability dimensions as the independent variable.

As shown in table 8, the entire model has a significant effect on E-Government Portals Quality $(\mathrm{p}=0.000<0.01)$. In the complete model for all the predictors, R2explains $52.9 \%$ of the variance related to E-Government Portals Quality, and consequently supports hypothesis $\mathrm{H} 1$

Table 8: Results of Multiple LinearRegression Analysis for E-Government Portals Quality (dependent variable) and Usability dimensions (independent variables)

\begin{tabular}{|c|c|c|c|c|c|}
\hline \multirow[t]{2}{*}{ Model (Independent Variables) } & \multicolumn{2}{|c|}{$\begin{array}{l}\text { Unstandardized } \\
\text { Coefficients }\end{array}$} & \multirow{2}{*}{$\begin{array}{c}\begin{array}{c}\text { standardized } \\
\text { Coefficients }\end{array} \\
\text { Beta }\end{array}$} & \multirow[t]{2}{*}{$\mathbf{T}$} & \multirow[t]{2}{*}{ Sig. } \\
\hline & B & Std.Error & & & \\
\hline H1 $_{\mathrm{a}}$ Effectiveness (EV) & .174 & .014 & .253 & 12.456 & $.000 * * *$ \\
\hline $\mathbf{H 1}_{\mathbf{b}}$ :Efficiency $(\mathrm{EY})$ & -.053 & .014 & -.059 & -3.753 & $.000 * * *$ \\
\hline H1 $\mathbf{c}_{\mathbf{c}}$ :Accessibility (AC) & .105 & .013 & .166 & 8.080 & $.000 * * *$ \\
\hline $\mathbf{H 1}_{\mathrm{d}}$ :Navigation $(\mathrm{N})$ & .037 & .013 & .054 & 2.768 & $.006^{* * *}$ \\
\hline H1 $1_{\mathrm{e}}$ :Website content(WC) & .140 & .017 & .195 & 8.331 & $.000 * * *$ \\
\hline H1 $1_{\mathbf{f}}$ :Learnability(L) & .089 & .016 & .127 & 5.442 & $.000 * * *$ \\
\hline H1 $1_{\mathrm{g}}$ :Interface design(ID) & .054 & .015 & .070 & 3.589 & $.000 * * *$ \\
\hline \multicolumn{6}{|c|}{ Equation } \\
\hline $\mathrm{R}$ & \multicolumn{5}{|c|}{.727} \\
\hline $\mathrm{R}^{2}$ & \multicolumn{5}{|c|}{.529} \\
\hline $\mathrm{F}$ & \multicolumn{5}{|c|}{$547.688 * * *$} \\
\hline
\end{tabular}

$* * * \mathrm{P}<0.01, * \mathrm{P}<0.1 \sim$ Dependent Variables: Portal Quality (PQ) 
As shown in the table above, the Standardized coefficient (beta) value for $\mathrm{EV}$ is positive and significant $(\mathrm{p}=0.000<0.01)$, and thus supports hypothesis H1a. The Standardized coefficient (beta) value for EY is negative and significant $(0.000<0.01)$, therefore supports hypothesis H1b. the Standardized coefficient (beta) value for $\mathrm{AC}$ is positive and significant $(p=0.000<0.01)$, and consequently supports hypothesis H1c. the Standardized coefficient (beta) value for $\mathrm{N}$ is positive and significant $(\mathrm{p}=0.006<0.01)$, and therefore supports hypothesis H1d. the Standardized coefficient (beta) value for WCis positive and significant $(0.000<0.01)$, and thus supports hypothesis H1e.The Standardized coefficient (beta) value for $\mathrm{L}$ is positive and significant $(0.000<0.01)$, and consequently supports hypothesis H1f.The Standardized coefficient (beta) value for ID is positive and significant $(0.000<0.01)$, therefore supports hypothesis $\mathrm{H} 1 \mathrm{~g}$.

\section{Hypothesis 2: Portal Security vs. E- Government Portals Quality}

To test this hypothesis, Multiple Regression Analysis (coefficient beta) was utilized between E-Government Portals Quality(PQ), as a dependent variable, and security dimensions as independent variables. As demonstrated in table 9, the entire model has a significant effect on $\mathrm{PQ}(\mathrm{p}=0.000<0.01)$. In addition, R2 can explain $43.4 \%$ of the variance related to PQ; and hence supports hypothesis $\mathbf{H} \mathbf{2}$.

Table 9: Results of MultipleLinear Regression Analysis for E-Government Portals Quality (PQ) (dependent variable) and Security dimensions (independent variables)

\begin{tabular}{|c|c|c|c|c|c|}
\hline \multirow[t]{2}{*}{ Model (Independent Variables ) } & \multicolumn{2}{|c|}{$\begin{array}{c}\text { Unstandardized } \\
\text { Coefficients }\end{array}$} & \multirow{2}{*}{$\begin{array}{c}\begin{array}{c}\text { standardized } \\
\text { Coefficients }\end{array} \\
\text { Beta }\end{array}$} & \multirow[t]{2}{*}{$\mathbf{t}$} & \multirow[t]{2}{*}{ Sig. } \\
\hline & B & Std.Error & & & \\
\hline $\mathbf{H 2}_{\mathrm{a}}$ :Confidentiality(CO) & .417 & .014 & .543 & 28.964 & $.000 * * *$ \\
\hline $\mathbf{H} \mathbf{2}_{\mathrm{b}}$ :Identity authentication(IA) & .117 & .015 & .148 & 7.884 & $.000 * * *$ \\
\hline \multicolumn{6}{|c|}{ Equation } \\
\hline $\mathrm{R}$ & \multicolumn{5}{|c|}{.659} \\
\hline $\mathrm{R}^{2}$ & \multicolumn{5}{|c|}{.434} \\
\hline $\mathrm{F}$ & \multicolumn{5}{|c|}{$1312.968 * * *$} \\
\hline
\end{tabular}

***P $<0.01, * \mathrm{P}<0.1 \sim$ Dependent Variables: PortalQuality(PQ) As per the above table, the Standardized coefficient (beta) value for $\mathrm{CO}$ is positive and significant $(\mathrm{p}=0.000<0.01)$, and therefore supports hypothesis H2a.the Standardized coefficient (beta) value for IA is positive and significant $(0.000<0.01)$, and thus supports hypothesis H2b.
Hypothesis 3: Portal Responsiveness vs. E-Government Portals Quality

To test this hypothesis, Simple Linear Regression Analysis (coefficient beta) was utilized between E-Government Portals Quality (PQ), as the dependent variable, and Portal Responsiveness as the independent variable. As illustrated in table 10 , the entire model has a significant effect on PQ $(\mathrm{p}=0.000<0.01)$. In the entire model, $\mathrm{R} 2$ explains $62.1 \%$ of the variance related PQ.This supports hypothesis $\mathbf{H 3}$

Table 10: Results of SimpleLinearRegression Analysis for E-Government Portals Quality (PQ) (dependent variable) and Responsiveness (independent variables)

\begin{tabular}{|c|c|c|c|c|c|}
\hline \multirow[t]{2}{*}{ Model (Independent Variables) } & \multicolumn{2}{|c|}{$\begin{array}{c}\text { Unstandardized } \\
\text { Coefficients }\end{array}$} & $\begin{array}{l}\text { standardized } \\
\text { Coefficients }\end{array}$ & $\mathbf{t}$ & Sig. \\
\hline & B & Std.Error & Beta & & \\
\hline H3:Responsiveness(RS) & .277 & .010 & .573 & 27.769 & $.000 * * *$ \\
\hline \multicolumn{6}{|c|}{ Equation } \\
\hline $\mathrm{R}$ & \multicolumn{5}{|c|}{.788} \\
\hline $\mathrm{R}^{2}$ & \multicolumn{5}{|c|}{.621} \\
\hline $\mathrm{F}$ & \multicolumn{5}{|c|}{$1867.772 * * *$} \\
\hline
\end{tabular}

***P<0.01, *P<0.1 Dependent Variables: Portal Quality (PQ) 


\subsection{One-Way Analysis of Variance Anova: Analysis of the Effect of Respondents' Perception of Usability, Security, and Responsiveness on their Evaluation of E-Government Portals Quality:}

One-Way Analysis of variance (ANOVA) was used between e-government portals quality as a dependent variable and usability, security, and responsiveness as independent variables. The results of this analysis demonstrate that the value of $F$ is 1867.772 at (0.000) level of significance. This means the acceptance of the hypotheses of USR framework, which stated that usability, security and responsiveness did not vary as per an individuals' evaluation of e-government Portals Quality. It is therefore to be inferred that there is a significant relationship between usability, security, and responsiveness with e-government portals quality. These upshots are illustrated in table 11.

Table 11: One-Way Analysis of Variance Anova: Analysis of the Effect of Respondents' Perception of Usability, Security, and Responsiveness on their Evaluation of E-Government Portals Quality

\begin{tabular}{|c|c|c|c|c|}
\hline Source of variance & Sum of squares & d.f & Mean square & F \\
\hline 1.Between Groups & 8501.852 & 4 & 2833.951 & 1867.772 \\
\hline 2. Within Groups & 5187.614 & 3419 & 1.517 & .000 \\
\hline Total & 13689.466 & & 3423 \\
\hline
\end{tabular}

Moreover, in order to test the current study's framework's dimensions, Univariate Analysis of Variance (UANOVA) was used. The research's framework proposes that the framework will be applicable to assess e-government portals' quality whether high or low. The mean, standard deviation and numbers of those who evaluate e-government portals quality as high is $\mathrm{M}=3.4002, \mathrm{SD}=1.15862, \mathrm{n}=2622$, whereas the mean. Standard deviation, and numbers of those evaluate egovernment portals quality as low is $\mathrm{M}=3.7371, \mathrm{SD}=1.12063$, $\mathrm{n}=801$. Where $\mathrm{F}=1867.772$ at $(\mathrm{p}=<0.000) 0.000$ significant level. Thus, this could be explained by differences between evaluation ofe-government portals' quality (high or low). Significantly, this confirms the applicability of the current study's framework in assessing e-government portals quality.

Table 12: Descriptive Statistics the Assessing of E-Government Portals' Quality

\begin{tabular}{|c|c|c|c|}
\hline e-government portals' quality & Mean & Std. Deviation & N \\
\hline Agree & 3.4002 & 1.15862 & 2622 \\
\hline Disagree & 3.7371 & 1.12063 & 801 \\
\hline Total & $\mathbf{3 . 5 6 8 7}$ & $\mathbf{2 . 2 7 9 2 5}$ & $\mathbf{3 4 2 3}$ \\
\hline
\end{tabular}

\section{CONCLUSION AND FUTURE WORK}

The e-government portals quality assessment (USR) framework was developed for quality assessment egovernment portals in Saudi Arabia. The framework contains three main dimensions: usability, security and responsiveness. To reach better measurement of quality, usability and security contains sub dimensions. To test the hypothesis of the research, a questionnaire was distributed through social media. Using multivariate statistical techniques, the findings indicate a clear relationship between portal usability, security and responsiveness with e-government portals quality.

The results revealed interesting insights with the concideration of determinant dimensions influencing the quality of electronic government portals, some future work may be addressed. For instance, adding more dimensions to the framework may cover more aspects of the quality of service provided by these portals. Besides, this study concentrated only on three e-government websites. Including more governmental websites in the assessment may reveal various results.

\section{REFERENCES}

[1] Fang, Z. (2002). E-Government in Digital Era: Concept, Practice, and Development, Thailand.

[2] Jaeger, P. T., \&Bertot, J. C. (2010). Transparency and technological change: Ensuring equal and sustained public access to government information. Government Information Quarterly, 27(4), 371-376.

[3] Bretschneider, S., Gant, J., \& Wang, Lili. (2005). Evaluating Web-Based E-Government Services with a Citizen-Centric Approach. Proceedings of the 38th Annual Hawaii International Conference on System Sciences. 
[4] Dhillon, G. S., Weerakkody, V., \& Dwivedi, Y. K. (2008). Realising transformational stage e-government: a UK local authority perspective. Electronic Government, An International Journal, 5(2), 162-180

[5] Luburić. R. (2014) "Total quality management as a paradigm of business success," Journal of Central Banking Theory and Practice, vol. 3, no.1, pp. 59-80.

[6] Halaris C., Magoutas B., Papadomichelaki X., Mentzas X. (2007), "Classification and synthesis of quality approaches in e-government services", Emerald Group Publishing Limited, Internet Research, Vol. 17 Iss: 4, pp.378 - 401 .

[7] Parasuraman, A. (2002), "Technology readiness and eservice quality: insights for effective e-commerce", ECommerce Seminar Series North Carolina State University, Raleigh, NC, 17 April.

[8] Bhattacharya D., Gulla U., Gupta M.P. (2012), "Eservice quality model for Indian government portals: citizens' perspective", Journal of Enterprise Information Management, Vol. 25 Iss: 3, pp.246 - 271.

[9] ISO (2005), Quality management systems Fundamentals and vocabulary - ISO 9000:2005.

[10] Venkatesh, V., \& Ramesh, V. (2006). Web and wireless site usability: Understanding differences and modeling use. MIS Quarterly, 30(1), 181-206.

[11] Pedley, M. (2007). Web Usability. http://accessites.org/site/2007/07/web-usability.

[12] Layton, T. (2007). Information Security: Design, Implementation, Measurement, and Compliance. Boca Raton, FL: Auerbach publications.

[13] Basu, S. (2004). E-government and Developing Countries: an Overview. International Review of Law Computers andTechnology, 18, (1), 109-133.

[14] Yang, Z. And Jun, M. (2002), "Consumer perception of e-service quality: From Internet purchaser and non purchaser perspectives", Journal of Business Strategies, Vol. 19, No. 1, pp. 19-41.

[15] Al-Khalifa, H. S. (2010). Heuristic evaluation of the usability of e-government websites: a case from Saudi Arabia. Paper presented at the Proceedings of the 4th International Conference on Theory and Practice of Electronic Governance.

[16] Alanezi, M.A., Kamil, A., \& Basri, S. (2010). A proposed instrument dimensions for measuring egovernment service quality. International Journal of U\& E-Service, Science \& Technology, 3(4), 1-18.

[17] Papadomichelaki, X \&Mentzas, G (2012), “e-GovQual: A multiple item scale for assessing e-government service quality", Government Information Quarterly, n.29, pp. 98-109.

[18] Almalki, O., Duan, Y. and Frommholz, I. (2013). "Developing a conceptual framework to evaluate egovernment portals' success," in Proceedings of the 13 European Conference on e-Government, E. Ferrari, W. Castelnovo, Eds. University of Insubria, 13-14 June 2013, 1, pp. 19-26.

[19] Ziemba, E. Papaj,T. and Descours, D. (2014). Assessing the quality of e-government portals - the Polish experience, Proceedings of the 2014 Federated Conference on Computer Science and Information Systems, Vol.2, pp. 1259-1267.

[20] Yahya, H., \& Razali, R. (2015). A usability-based framework for electronic government systems development. ARPN J. Eng. Appl. Sci, 10(20), 9414 9423 .

[21] Al-Khalifa, H. S., Baazeem, I., \& Alamer, R. (2017). Revisiting the accessibility of Saudi Arabia government websites. Universal Access in the Information Society, 16(4), 1027-1039 .

[22] Al-Hawary, S. I. S., \& Al-Menhaly, S. M. (2017). The Quality of E-Government Services and its Role on Achieving Beneficiaries Satisfaction. Global Journal of Management And Business Research .

[23] Sterrenberg, G, (2017). A Conceptual Framework for Evaluating E-Government Systems Success: A Service Ecosystem Approach, Proceedings of the 50th Hawaii International Conference on System Sciences, 2017.

[24] Heeks R, (2001) Building E-Governance for development: A framework for National and Donor Actions, working paper, NO.12, ISDPM, university of Manchester, Manchester.

[25] https://www.usability.gov/

[26] Fernandez, A., Insfran, E., \& Abrahão, S. (2011). Usability evaluation methods for the web: A systematic mapping study. Information and Software Technology, 53(8), 789-817.

[27] Marsico, M. De, \&Levialdi, S. (2004). Evaluating web sites: exploiting user's expectations. International Journal of Human-Computer Studies, 60(3), 381-416.

[28] Aziz. N, and Kamaludin. A, (2015) development of instrument for evaluating website usability focusing on university website, Proceedings of the 5th International Conference on Computing and Informatics, ICOCI 201511-13 August, 2015 Istanbul, Turkey. Universiti Utara Malaysia.

[29] Wang, J., \&Senecal, S. (2008). Measuring Perceived Website Usability. Journal of Internet Commerce, 6(4), 97-112.

[30] Palmer, J. W. (2002). Web site usability, design , and performance metrics.

[31] Macleod M and Rengger R. (1993) The Development of DRUM: A Software Tool for Video-assisted Usability Evaluation. In: People and Computers VIII, Proceedings of the HCI'93 Conference (Loughborough, UK, Sept 1993), CUP.

[32] Anjoga. H, Nyeko. S, and Kituyi. M (2017) A Framework for Usability of e-Government service in developing countries, Journal of Accounting and Auditing: Research \& Practice.

[33] Nielsen, J. (1994). Enhancing the explanatory power of usability heuristics. In Proceedings of the SIGCHI conference on Human Factors in Computing Systems, 152-158.

[34] IT Project Center (2013). Analysis of Good Practice in the Area of E-government (Analiza Dobrych Praktyk w Obszarze E-administracji), Warsaw, 2013. 
[35] Stowers, G. (2002). The State of Federal Websites: The Pursuit of Excellence, August 2002.

[36] Venkatesh. V, Hoehle. H, and Aljafari. R, (2014), A usability evaluation of the Obamacare website, Government Information Quarterly, 33, pp. 669-680.

[37] ISO/IEC (2011), Systems and software engineering. Systems andSoftware quality. Requirements and Evaluation (SQuaRE). Systemand software quality models. ISO/IEC 25010:2011(E), InternationalOrganisation for Standardisation, Geneva, 2011.

[38] Caldwell, B., Chisholm, W., Vanderheiden, G. \& White, J. (2004). Web Content Accessibility Guidelines 2.0. W3C Working Draft 19 November 2004.

[39] Aziz. N. and Kamaludin. A, (2014), Assessing Website Usability Attributes Using Partial Least Squares, International Journal of Information and Electronics Engineering, 4(2).

[40] West, D. (2002). Global E-Government. Retrieved from http://www.insidepolit ics.org/egovt02int.html.

[41] Accenture, (2005). Leadership in Customer Service: New Expectations, New Experiences. The Government Executive Series, April 2005.

[42] Criado, J.I. and Ramilo. M.C, (2003). E-Government in practice: an analysis of website orientation to citizens in Spanish municipalities. International Journal of Public Sector Management, 18(3), 191-218.

[43] Loiacono, E., Watson, R., \& Goodhue, D. (2007). WebQual: An Instrument for Consumer Evaluation of Web Sites. International Journal of Electronic Commerce, 11(3), 51-87.

[44] Sharifia, M. and A. Manian,(2010). The study of the success indicators for pre-implementation activities of Iran's E-government development projects. Gov. Inform. Q., 27: 63-69.

[45] Lee, Y., \&Kozar, K. a. (2012). Understanding of website usability: Specifying and measuring constructs and their relationships. Decision Support Systems, 52(2), 450463. doi:10.1016/j.dss.2011.10.004.

[46] Cyr, D. (2013). Website design, trust and culture: An eight country investigation. Electronic Commerce
Research and Applications, 12(6), 373-385.

[47] Agarwal, R., \& Venkatesh, V. (2002). Assessing a firm's web presence: A heuristic evaluation procedure for the measurement of usability. Information Systems Research, 13(2),168-186.

[48] Kalakota, R., \&Whinston, A. (1996). Frontiers of Electronic Commerce. Reading, MA: Addison-Wesley.

[49] Zhang, P., \& von Dran, G. (2001). User Expectations and Rankings of Quality Factors in Different Web Site Domains. International Journal of Electronic Commerce, 6(2), 9-33.

[50] Anil Saldhana, (2007) "secure e-government portals", W3C Workshop on e-Government and the Web, National Academy of Sciences, Washington.

[51] Kelsey. J, Stefan. L, Schneier. B, Stay. M, Wagner. D, and Whiting. D, (2000) "Improved Cryptanalysis of Rijndael".

[52] Teeter, R., \& Hart, p., (2003). The new e-government equation: ease, engagement, privacy and protection. The council for Excellence in Government

[53] Shanshan. Sh. (2014), Assessment of E-government Service Quality under User Satisfaction Orientation: The Establishment of E-Govqual Model, Asian Journal of Business Management 6(2): 111-117, 2014.

[54] https://www.alexa.com/topsites

[55] Mason, S. J. and Graham, N. E. 1999. Conditional probabilities, relative operating characteristics, and relative operating levels. Wea. Forecasting 14, 713-725.

[56] Hair. Jr, Black, B., and Anderson, 2010. Multivariate data analysis, 7th edition, Pearson Prentice Hall.

[57] Dinev, T. and Hart, P. (2002) Internet Privacy Concern and Trade-Off Factors: Empirical Study and Business Implications. Working paper, Florida Atlantic University.

[58] Hair, J.F.J, Bush, R.P., and Ortinau, D.J. (2000) Marketing Research: A Practical Approach for the New Millennium. Sydney: Irwin McGraw-Hill.

[59] Nunnally, J.C. (1978) Psychometric theory, 2nd ed. New York: Mc Graw-Hill. 